\title{
Niedokończony projekt, czyli sporu o reformę szkolnictwa wyższego ciąg dalszy
}

\section{Streszczenie}

Niniejszy tekst jest głosem w dyskusji nad reformą szkolnictwa wyższego w Polsce. Na wybranych przykładach pokazuje on, że planowane zmiany opierają się na kilku fundamentalnych mitach odpowiadających za nieefektywność wcześniejszych prób naprawy uniwersytetu. Jednocześnie stara się pokazać, dlaczego należy odrzucić przekonanie, że reformę szkolnictwa wyższego można przeprowadzić szybko, bez wielkich nakładów finansowych, i że rezultaty wprowadzanych zmian mogą być natychmiastowe. W tekście prowadzona jest także krytyka poglądu zakładającego, że pożądane zmiany można osiągnąć wyłącznie poprzez reformę prawa i że da się wprost zastosować $w$ warunkach polskich rozwiązania działające w innych państwach. Prowadzone rozważania przeciwstawiają się stanowisku, zgodnie z którym istnieją jakieś idealne modele kształcenia i prowadzenia badań, których wdrożenie umożliwia „wyhodowanie” idealnego uczonego. Argumentując, że kształcenie i sukces naukowy zawsze będą wypadkową wielu zmiennych, krytycznej analizie poddano również wybrane rozwiązania wprowadzane w prawie o szkolnictwie wyższym i nauce.

Słowa kluczowe: edukacja wyższa, reforma, model uniwersytetu, internacjonalizacja nauki

1 Dr hab. Wojciech Cyrul - Katedra Filozofii Prawa i Etyki Prawniczej Wydziału Prawa i Administracji Uniwersytetu Jagiellońskiego; e-mail: cyrulwojciech@hotmail.com; ORCID: 0000-0002-5629-869X.

2 Prof. dr hab. Jerzy Stelmach - kierownik Katedry Filozofii Prawa i Etyki Prawniczej Wydziału Prawa i Administracji Uniwersytetu Jagiellońskiego; e-mail: jstelmachivr@gmail.com; ORCID: 0000-0002-4188-5277. 


\title{
An unfinished project or the dispute over the reform of higher education continued
}

\begin{abstract}
This text is a contribution to the discussion on the reform of higher education in Poland. By referring to selected examples, it shows that the planned changes are based on several fundamental myths resulting from the inefficiency of earlier attempts to heal the university system. At the same time, it aims to show why it is necessary to abandon the belief that higher education can be reformed quickly, with little financial outlays, and that the results of the implemented changes can be instant. The text offers also a criticism of the view assuming that the expected changes can be arrived at only through a reform of the law, and that it is possible to transplant solutions functioning in other countries directly to Poland. The presented considerations oppose the position according to which there exist some ideal models of education and research, whose implementation can make it possible to "breed" an ideal scholar. Arguing that education and academic success will always be an outcome of many variables, a critical analysis of selected solutions included in the law on science and higher education has been offered as well.
\end{abstract}

Keywords: Keywords: higher education, reform, university model, internationalisation of education 
$\mathrm{S}$ pór o model kształcenia uniwersyteckiego (rozumiemy tu uniwersytet w najszerszy z możliwych sposób) trwa tak długo, jak istnieją uniwersytety i najpewniej będzie trwał zawsze. W sporze tym uczestniczy z jednej strony środowisko akademickie, z drugiej zaś decydujący o pieniądzach politycy. Nie znaczy to jednak wcale, że główni uczestnicy debaty mówią tym samym głosem. Bynajmniej nie! Każda grupa ma własne interesy, najczęściej sprzeczne z interesami pozostałych. Gdy idzie o środowisko akademickie, to inaczej o reformie będą mówić „przyrodnicy”, inaczej „'medycy", a jeszcze inaczej „humaniści”. Z podobnym zróżnicowaniem będziemy mieli do czynienia po stronie polityków. Inaczej reformę wyobrażać sobie będzie prawica, inaczej liberałowie, a jeszcze inaczej lewica. W zasadzie wszystkich dzieli wszystko. Ale, o dziwo, są jednak pewne punkty wspólne, a są nimi egoizm oraz minimalizm. Każdy bowiem z uczestniczących $w$ tej debacie chce, aby to "jego chata zawsze była z kraja”, a ponadto chce, aby zmieniać system tak, żeby go w gruncie rzeczy w ogóle nie zmienić. I dlatego pewnie jeszcze trochę sobie "pogadamy” i „poreformujemy”. A Kampus jak był dziadowski, takim najpewniej pozostanie, bo na końcu i tak okaże się, że na reformę, taką, czy inną, jak zwykle zabraknie pieniędzy.

Nieefektywność kolejnych, nie tylko zresztą polskich, reform wynika z co najmniej sześciu mitów, na których wspiera się myślenie o idei naprawy uniwersytetu. Mit pierwszy, że można to zrobić szybko. Wszyscy, zarówno uczeni, jak i politycy, oczekują natychmiastowych rezultatów, w przypadku tych pierwszych większych przywilejów i szerszej autonomii, a tych drugich, dającego się propagandowo wykorzystać przekazu. A przecież nawet średnio zorientowane w kwestii funkcjonowania uniwersytetu osoby muszą przecież zdawać sobie sprawę z tego, że rezultaty pewnych reform mogą pojawić się, jeśli w ogóle, dopiero po wielu latach. Racjonalna reforma oznacza długotrwały, tak naprawdę pokoleniowy proces ewolucyjnych zmian, w trakcie którego dochodzi do zmiany sposobu myślenia o uniwersytecie całego środowiska naukowego. $W$ procesie tym powinny w szczególności zostać wypracowane i zastosowane nowe jakościowe i ilościowe standardy służące ocenie pracy naukowej i dydaktycznej. Mit drugi, że można to osiągnąć wyłącznie poprzez reformę prawa. Najłatwiej i najszybciej jest przecież przygotować i uchwalić nową ustawę. Znacznie trudniej jest wprowadzić ją w życie, mówiąc inaczej, urzeczywistnić zapowiedzianą reformę. Zwykle zawarte w ustawie propozycje zmian są bardziej wyrazem „pobożnych życzeń”, niż rzeczywistym programem reform. Dlatego pewnie tak często zaraz po uchwaleniu nowego prawa 
rozpoczyna się debata na temat jego zmiany. Mit trzeci, że da się wprost zastosować działające gdzie indziej rozwiązania. Zarówno uczeni, jak i politycy z zaangażowaniem godnym lepszej sprawy poszukują idealnego wzorca dla reformy uniwersytetu. Większość zwolenników radykalnych zmian w Polsce opowiada się za przyjęciem rozwiązań działających w innych systemach naukowych, najczęściej anglosaskich. W szczególności bezkrytycznie przejmuje się wypracowane tam rozwiązania dotyczące "punktowej wyceny wartości publikacji naukowych" oraz „zasad uwzględniania cytowań". A jedynym póki co rezultatem są bardzo odległe miejsca naszych najlepszych uniwersytetów w „wymyślonych” przez innych, podobnie zresztą jak inne rozwiązania, rankingach. Każdy, kto miał okazję poznać przynajmniej niektóre umieszczane na czele rankingów uniwersytety, w których, ujmując rzecz dość delikatnie, nic szczególnego się nie dzieje, musi się zgodzić, że taki sposób oceniania jest rażąco niesprawiedliwy. Przyjmując cudze "reguły gry" sami skazujemy się na marginalizację. Mit czwarty, że można dokonać tego bez wielkich pieniędzy. Mit ten opiera się na przekonaniu, że wystarczy się tylko bardziej starać, a sukcesy przyjdą same. Uchwalimy nową ustawę, złożymy jakieś nie do końca jasne obietnice dla środowiska akademickiego i wszystko potoczy się w dobrym kierunku. To oczywista bzdura, o której można nieco więcej powiedzieć, odwołując się do, przywoływanego zresztą często przez „reformatorów”, przykładu Uniwersytetu Harvarda. Ta skądinąd wybitna uczelnia dysponuje środkami finansowymi porównywalnymi z tymi, które są przeznaczane na całe polskie szkolnictwo wyższe. Harvard obok ogromnych rezerw finansowych otrzymuje bardzo wysoką dotację państwową, zarabia krocie na kształceniu i wreszcie otrzymuje niezliczoną ilość darowizn od instytucji i osób prywatnych. O czym więc my tu mówimy? Przypadek Harvardu pokazuje zaledwie tyle, że należy walczyć z omawianym tu mitem oraz że pieniądze powinny być zdywersyfikowane, jeśli rzeczywiście mają efektywnie służyć rozwojowi danej instytucji naukowej. Mit piąty, że stosunkowo łatwo można „wyhodować” idealnego uczonego. Znów będzie chodzić o naszym zdaniem całkowicie fałszywe wyobrażenie, że da się proces kształcenia i rozwoju kadry naukowej zadekretować ustawowo, że wystarczy sama reforma i już zaczniemy odnosić sukcesy. Wystarczy znieść habilitację, uprościć procedurę awansową, zwiększyć liczbę doktorantów i „hodowla” ruszy pełną parą. Warto może przy tej okazji przypomnieć kompletną klapę programu „profesorów juniorów” w Niemczech, czy zwrócić uwagę, o czym już zresztą wcześniej pisaliśmy, że stosowanie rozwiązań awansowych wypracowanych w innych miejscach, na przykład w krajach anglosaskich, może okazać się, wobec innego otoczenia i tradycji, zabiegiem całkowicie nieefektywnym. I tak, koniecznym warunkiem rozwoju kadry w naukach przyrodniczych będzie udział w ponadnarodowych programach badawczych oraz współpraca z najlepszymi ośrodkami naukowymi na świecie. 
Natomiast w naukach w humanistycznych zawsze będzie chodzić tylko o „wyłowienie" pojedynczych indywidualności, których nigdy i nigdzie na większą skalę nie udało się „wyhodować”. Mit szósty, że da się stworzyć "optymalny model kształcenia". Kształcenie zawsze będzie wypadkową wielu zmiennych. Przede wszystkim takich jak określona sytuacja polityczna i ekonomiczna danego kraju, tradycja związana z danym miejscem, efektywność dotychczas stosowanych oraz możliwa efektywność proponowanych metod, jakość kadry, którą dysponuje dana jednostka naukowa, czy wreszcie zmieniające się w różnych okresach motywacje samych studiujących. Jest to $\mathrm{w}$ istocie ciągły proces zmian i dostosowań, gdzie niczego nie da się ustalić raz na zawsze, a już na pewno nie za pomocą przepisów ustawy.

Formalne podstawy każdej możliwej reformy powinny być w gruncie rzeczy podobne. Po pierwsze, należy jednoznacznie określić główny cel reformy. W szczególności należy rozstrzygnąć, jaki model uniwersytetu będziemy chcieli zaproponować: elitarny, czyli uniwersytet dla wybranych, czy egalitarny, czyli uniwersytet poniekąd dla wszystkich. Każda próba połączenia, znalezienia kompromisu pomiędzy tymi dwoma punktami widzenia zawsze będzie oznaczać załamanie się reformy. Po drugie, należy określić kilka najważniejszych założeń, czyli przyjąć program pewnego koniecznego minimum, który dotyczyłby takich kluczowych kwestii jak: autonomia uniwersytetu, decentralizacja systemu zarządzania, spójne, uwzględniające specyfikę danego systemu, a nie bezmyślnie przejmowane z zewnątrz zasady parametryzacji (oceny naukowej), konkursy na obsadę stanowisk naukowych w uniwersytecie, sposoby zatrudniania pracowników naukowych czy wreszcie dywersyfikacja płac. Dopiero po określeniu i przedyskutowaniu takich założeń można podejmować próby stworzenia spójnego modelu reformy. Rozpoczynanie reformy od liczącej tysiące zapisów szczegółowej regulacji jest w naszym przekonaniu przedsięwzięciem z góry skazanym na niepowodzenie. Niestety takie rozwiązanie przyjął 3 lipca 2018 r. Sejm RP, uchwalając Prawo o szkolnictwie wyższym i nauce.

Nie będziemy poniżej analizować poszczególnych przepisów ustawy, na to przyjdzie jeszcze czas. Teraz znacznie ważniejsze jest pytanie, czy przyjęcie nowej ustawy rzeczywiście oznacza rewolucję w systemie szkolnictwa wyższego, czy jest tylko wyrazem niespełnionych ambicji części środowiska akademickiego i próbą zaklinania rzeczywistości przez polityków. A może mamy do czynienia z rozsądną transformacją i uporządkowaniem systemu szkolnictwa wyższego z wprowadzeniem rozwiązań, które dają znacznie większe szanse polskiej nauce na umiędzynarodowienie niż miała ona dotychczas? Niestety główne cele reformy, tj. zrównoważony rozwój i umiędzynarodowienie polskiej nauki i szkolnictwa wyższego, są tak ogólne, że trudno jest oceniać reformę bez analizy środków, za pomocą których reformatorzy przyjęte cele chcą realizować. Wiele niestety wskazuje na to, 
że u ich podstaw leżą te same mity, o których pisaliśmy wcześniej. Na przykład, trudno jest zrozumieć, jak nowe zasady parametryzacji nauki mają wspomagać rozwój humanistyki, jak wprowadzona reformą zmiana modelu kształcenia doktorantów ma podnieść jakość ich kształcenia, jak wprowadzone przez ustawodawcę nowe ścieżki kariery akademickiej mają sprzyjać podnoszeniu jakości kształcenia oraz pracy naukowej, jeśli nie powiązano z nimi żadnych nowych instrumentów motywacyjnych? Podobna wątpliwość wiąże się ze zmianami zasad zatrudnianiu pracowników naukowych. W szczególności nie jest jasne, jak mają one wspierać rozwój nauki polskiej i jej umiędzynarodowienie, biorąc pod uwagę fakt, że ustawa nadmiernie wspiera stabilność zatrudnienia osób zatrudnionych na podstawie umowy o pracę, a jednocześnie uderza w nauczycieli akademickich zatrudnionych na podstawie mianowania, a więc w większości osób posiadających tytuł naukowy profesora. Nie wprowadza ona także realnych zmian w systemie wynagradzania pracowników naukowych oraz osłabia zamiast wzmacniać rolę postępowań konkursowych. Mając na uwadze te i inne wątpliwości, nie można pozbyć się wrażenia, że reforma pogłębia raczej patologie istniejące w systemie, niż im przeciwdziała. Poniżej, na kilku przykładach, postaramy się pokazać, że przynajmniej niektóre ze zgłoszonych wątpliwości nie są całkowicie nieuzasadnione.

Trudno jest przewidzieć, czy nowe regulacje sprzyjać będą realizacji wartości, na które wskazuje preambuła. Trudno jest również dziś jednoznacznie ocenić, czy nowe regulacje pozwolą na realizacje ambitnych celów, jakie legły u podstaw reformy. Wiele jednak wskazuje na to, że i tym razem myślenie mityczne zwyciężyło nad zdrowym rozsądkiem i że znów będziemy świadkami kolejnej niedokończonej reformy. Grzechem pierworodnym twórców nowej ustawy jest bowiem brak jednoznacznego wykazania, że nowe rozwiązania są w stanie zagwarantować realizację jej celów. Pod górnolotnymi hasłami o profesjonalizacji zarządzania uczelniami, o poszerzaniu autonomii uczelni wyższych, o nowych ścieżkach kariery naukowej, o nowych zasadach oceny dorobku naukowego czy wreszcie o podniesieniu nakładów na szkolnictwo wyższe w rzeczywistości nie proponuje się nic specjalnego albo wręcz ukryte są rozwiązania jawnie sprzeczne z deklaracjami. Niestety jak zwykle albo zabrakło odwagi, albo wygrały animozje lub sprzeczne interesy poszczególnych grup zainteresowanych utrzymaniem status quo. Wystarczy przyjrzeć się budzącej tak duże kontrowersje radzie uczelni, a więc instytucji wcale nie takiej zupełnie nowej w polskim systemie szkolnictwa wyższego. Przecież rady tego typu funkcjonowały przez jakiś czas po nowelizacji ustawy o szkolnictwie wyższym z grudnia 1968 r., mówienie więc, że wprowadza się rozwiązanie funkcjonujące na najlepszych uczelniach zachodnich, traktować można jedynie jako chwyt retoryczny. To nie istnienie rady uczelni lub jej brak są istotne, ale jej rola, status prawny, kompetencje i skład osobowy. W wersji ustawy przyjętej przez sejm radę uczelni 
pozbawiono wielu wcześniej planowanych kompetencji wykonawczych i sprowadzono ją zasadniczo do ciała doradczego i nadzorczego. Analizując obecny charakter tej instytucji, można dojść do wniosku, że jedynym pewnym skutkiem jej utworzenia - poza oczywistym ograniczeniem podmiotowości zewnętrznej uczelni - będą kolejne obciążenia finansowe, jakie będą musiały one ponosić w związku z koniecznością wypłaty wynagrodzeń dla członków rady. Oczywiście może się okazać, że członkami tego gremium zostaną ludzie wybitni, których doświadczenie, kontakty i umiejętności wniosą nową jakość do zarządzania uczelnią. Gwarancji, że tak będzie, nowa ustawa jednak nie daje, ponieważ wymogi, jakie stawia przed kandydatami, są tak niskie, że w praktyce ich członkiem może zostać prawie każda niekarana osoba posiadająca wyższe wykształcenie, która korzysta z pełni praw publicznych i ma pełną zdolność do czynności prawnych. Ustawa zakazuje jedynie łączenia członkostwa w radzie uczelni z pełnieniem funkcji organu tej lub innej uczelni, członkostwem $\mathrm{w}$ radzie innej uczelni i z zatrudnieniem $\mathrm{w}$ administracji publicznej. Nie zabrania jednak powoływania w skład rady uczelni czynnych polityków, przedstawicieli związków wyznaniowych czy osób, które nie dają rękojmi sprawowania funkcji członka rady zgodnie z wartościami akademickimi. Od razu pojawia się więc pytanie, po co było tworzyć ciało, które może zawłaszczone zostać przez lokalne układy lub osoby, które nie gwarantują ani światopoglądowej, ani politycznej neutralności. Nikomu nie zarzucamy złych intencji czy braku dobrej woli, ale jeśli chcemy profesjonalizować zarządzanie uczelniami, to od tych, w których ręce powierzamy dobro tak wielkie, jak uczelnie wyższe, powinniśmy chyba wymagać tego, czego chociażby wymagamy od tych, którym powierzamy mienie państwowe. Paradoksalnie nowa ustawa wprost stanowi, że do członków rad uczelni nie stosuje się przepisów art. 19 ustawy z dnia 16 grudnia 2016 r. o zasadach zarządzania mieniem państwowym (Dz.U. z 2018 r., poz. 1182). Mając na uwadze rolę rady uczelni, zaskakiwać musi również fakt, że w jej skład obligatoryjnie ma wejść przewodniczący samorządu studenckiego. Doceniając rolę samorządu studenckiego w funkcjonowaniu uczelni oraz konieczność właściwej reprezentacji studentów $w$ organach odpowiedzialnych za sprawy związane z kształtowaniem polityki naukowej uczelni oraz za dydaktykę, wydaje się jednak, że akurat $\mathrm{w}$ radach uczelni powinni zasiadać raczej wybitni eksperci, przedstawiciele interesariuszy zewnętrznych lub osoby, których dokonania wzbudzają szacunek i uznanie lokalnej społeczności, a nie osoby, które jeszcze się uczą.

Podobne wątpliwości budzi daleko idące wzmocnienie pozycji rektora, bez wyraźnego zaostrzenia kryteriów, jakie powinny spełniać osoby ubiegające się o to stanowisko. Nowa ustawa wyraźnie przewiduje, że do zadań rektora należą wszystkie sprawy dotyczące uczelni, z wyjątkiem spraw zastrzeżonych przez ustawę lub statut do kompetencji innych organów uczelni. Wprawdzie zarzucono, miejmy 
nadzieję ostatecznie, pomysł, aby rektora wybierała rada uczelni, ale wciąż trudno zrozumieć, czemu ma służyć omnipotencja rektora i skupienie w jednej osobie tak wielu prerogatyw. Na pewno nie uzasadnia tego powoływanie się na próbę wprowadzenie w Polsce modelu menedżerskiego w zarządzaniu uczelnią wyższą. Doświadczenie i podstawy wiedzy o zarządzaniu uczą, że nadmierna centralizacja sprzyja jedynie wzrostowi kosztów zarządzania. Jakości zarządzania sprzyjają właściwe procedury, kompetentne kadry oraz odpowiednia kontrola. Problem z przyjętym w ustawie rozwiązaniem polega przede wszystkim na tym, że od rektora, któremu ostatecznie powierzono pełnię władzy wykonawczej na uczelni, oczekuje się spełnienia zasadniczo tych samych kryteriów, jakie spełniać mają członkowie rady uczelni. Jedyny wymóg dodatkowy to posiadanie przez niego co najmniej stopnia doktora. Pytaniem retorycznym jest, czy osoba bez kierunkowego wykształcenia w zarządzaniu, bez podstaw wiedzy prawniczej i ekonomicznej i bez wieloletniego, międzynarodowego doświadczenia w zarządzaniu dużym podmiotem gospodarczym lub instytucją badawczą może profesjonalnie zarządzać uczelnią wyższą, przygotowywać jej strategie, prowadzić jej politykę kadrową i gospodarkę finansową. Oczywiście brak ustawowych kryteriów, jakie spełniać muszą rektorzy, i pozostawienie tej kwestii uczelniom funkcjonuje w niektórych krajach UE, takich jak np. Austria, Holandia czy Wielka Brytania. Kraje te mają jednak odmienną niż Polska kulturę akademicką, więc jeśli autorom reformy rzeczywiście zależało na profesjonalizacji uczelni wyższych, to należało wprowadzić przynajmniej wymóg międzynarodowych konkursów na stanowisko rektora albo wyraźnie ograniczyć funkcje rektora do funkcji reprezentacyjnych i akademickich, a zarządzanie uczelnią przekazać profesjonalnym menedżerom. Znowu zabrakło wizji lub górę wzięła wiara w mit, że poszczególne społeczności akademickie, często pozbawione odpowiednich środków i doświadczenia, będą w stanie wypracować i wdrożyć w tym zakresie właściwe mechanizmy. Szczególnie intrygujący jest w tym kontekście fakt, że rozszerzeniu kompetencji rektora nie towarzyszy jednoczesne wprowadzenie jasnych zasad rozliczalności i transparentności procesu zarządzania uczelnią. Bez takich zasad trudno mówić o jakiejkolwiek profesjonalizacji, a aktualny staje się zarzut, że wprowadzane ustawą rozwiązanie sprzyjać będzie przejmowaniu procesów decyzyjnych na uczelniach przez wąskie grupy osób uprzywilejowanych oraz dalszemu ograniczaniu podmiotowości pozostałych pracowników uczelni oraz studentów.

Mając powyższe na uwadze, wydaje się, że łatwiejsze zarządzanie strumieniami finansowania wcale nie będzie sprzyjać bardziej efektywnemu ich wydawaniu, przynajmniej z perspektywy realizacji celów reformy. Co więcej, powyższe wątpliwości uzasadniają wniosek, że nowa struktura systemu szkolnictwa, nawet jeśli wprowadza wiele trafnych rozwiązań, takich jak chociażby możliwość tworzenia 
federacji uczelni, nie gwarantuje, że system ten sprosta wyzwaniom społecznym i gospodarczym, jakie przed nim postawiono. Niestety w obecnej kondycji polskich uczelni oraz środowiska akademickiego wiara w mit, że reformy mogą dokonać się szybko i że wystarczy tylko wprowadzić właściwe przepisy prawne, może okazać się ryzykowna, nie tylko dla poszczególnych uczelni, ale także dla finansów publicznych. Przekonanie, że zmiany strukturalne można wprowadzić szybko, a nakłady finansowe stopniowo, skutkuje tym, że zamiast przetestować nowe rozwiązania w ramach programów pilotażowych w kontrolowanych warunkach na kilku wybranych uczelniach, opracowuje się i wprowadza się rozwiązania, co do których nie mamy pewności, że okażą się skuteczne. Rozsądek i doświadczenie podpowiadają, że, zanim zmieni się cały system, należy sprawdzić, jak działają określone rozwiązania, i obserwować, czy skutki, do jakich prowadzą, zgodne są z oczekiwaniami czy nie. Takich prób jednak nie przeprowadzono. Ponownie okazało się, że jesteśmy niepoprawnymi romantykami, kierującymi się emocjami, a nie rozumem, preferującymi spektakularne działania, wielkie hasła i eksperymenty na żywym organizmie, a nie reformy stopniowe, dobrze przygotowane i oparte na rozwiązaniach, które sprawdziły się w warunkach polskich i z uwzględnieniem specyfiki polskiej kultury akademickiej i stopnia gospodarczego rozwoju Polski. Niestety eksperymenty, w szczególności te źle przygotowane i nieprzemyślane, bardzo często się nie udają, więc i w analizowanym przypadku wieszczenie reformie sukcesu może okazać się płonne. Najpewniej jednak czekać nas będzie długi okres chaosu i to, co dotychczas jeszcze jakoś działało, przestanie działać.

Megalomania i wiara w mit o skuteczności prawa w zarządzaniu zmianą społeczną i przekonanie o własnej nieomylności decydentów pchnęły nas wszystkich w rewiry niezbadane, zapewne pełne dobrych intencji, ale niepoparte ani realną wiedzą, ani doświadczeniem. Zamiast stopniowo, krok po kroku poprawiać istniejące instytucje, wprowadza się nowe, niesprawdzone w naszej kulturze rozwiązania. Zamiast zastanowić się nad tym, jaki model uniwersytetu mamy obecnie i dlaczego właśnie taki, a nie inny, próbujemy nad Wisłą powtórzyć sukces modelu uniwersytetów anglosaskich, bez pieniędzy, bez odpowiedniego otoczenia biznesowego, bez tradycji, z którą model ten jest związany. Może warto by było porównać wyniki polskich uczelni z wynikami uczelni z pierwszej setki rankingu szanghajskiego z uwzględnieniem czynnika wysokości budżetów na badania i na wynagrodzenia. Mogłoby się okazać, że dotychczasowy system szkolnictwa wyższego, przy wszystkich jego wadach, wcale nie był aż tak zły, jak się wydaje i wprowadzenie mechanizmów motywujących oraz wsparcia dla pracowników naukowych mogłoby znacząco podnieść wpływ ich dorobku na światowy obieg myśli oraz poprawić wyniki, jakie osiągają oni w konkursach grantowych realizowanych przez Europejską Radę ds. Badań Naukowych. Innymi słowy, w celu umiędzynarodo- 
wienia polskiej nauki zamiast wielkiej reformy może wystarczyłoby mocniej powiązać wynagrodzenia z wynikami naukowymi osiąganymi przez pracowników uczelni, zapewnić uczelniom wyższym środki na zatrudnianie wybitnych, zagranicznych naukowców, stworzyć realne zachęty i zapewnić wsparcie dla naukowców gotowych przygotowywać wnioski w europejskich konkursach grantowych oraz wykorzystać $\mathrm{w}$ wyższym stopniu potencjał naukowy uczelni w projektach państwowych?

Mając na uwadze, że reforma przewiduje wzrost nakładów na naukę łącznie prawie o 50 mld złotych w ciągu najbliższej dekady, pojawia się pytanie, czy nowe prawo gwarantuje, że pieniądze te na pewno wejdą do systemu szkolnictwa wyższego oraz czy przyjęte przez sejm rozwiązania gwarantują, że pieniądze te nie zostaną zmarnowane. Oba pytania muszą zostać bez odpowiedzi, ponieważ brak jest rzetelnych i niezależnych analiz, które pokazałyby jednoznacznie, jaką część tej kwoty pochłoną same koszty wprowadzenia reformy oraz jakie będą koszty funkcjonowania nowych rozwiązań. Można mieć tylko nadzieję, że nie okażą się one znacznie wyższe niż przewidywano w ocenie skutków regulacji, i że do systemu nie wpłynie mniej pieniędzy niż planuje ministerstwo. $W$ przeciwnym razie będzie to kolejna nie tylko niedokończona, ale również chybiona reforma. Warto też pamiętać, że suma pieniędzy, jaką rząd planuje wydać dodatkowo na cały system szkolnictwa wyższego i na naukę w ciągu 10 lat, jest wielokrotnie mniejsza niż kwota, jaką w tym samym czasie dysponować będzie wspominany powyżej Uniwersytet Harvarda. Pomijając, że jego roczny przychód wynosi ok. 5 mld USD, to, jeśli nic się nie zmieni, dodatkowo uzyska on w ciągu najbliższej dekady rządowe dotacje na badania naukowe większe niż nowa ustawa przewiduje dla wszystkich polskich uczelni razem wziętych.

Zwolennicy reformy, pewnie słusznie, domagali się zmian. Słabe wyniki polskich uczelni w międzynarodowych rankingach nie pozostawiają bowiem złudzeń, że nie dzieje się z nimi najlepiej. Ministerstwo Nauki i Szkolnictwa Wyższego w przygotowanej do ustawy ocenie skutków regulacji jednoznacznie pokazało, że chociaż znacząco wzrósł w Polsce odsetek ludności posiadającej wyższe wykształcenie, to jednak nie przełożyło się to ani na podniesienie międzynarodowego statusu polskich uczelni, ani na jakość polskiej nauki. Nakłady na naukę i rozwój w Polsce na poziomie 1,0\% PKB lokują nasz kraj dopiero na 31. miejscu w gronie 35 państw członkowskich OECD. Zaproponowano wiele rozwiązań, takich jak np. wzrost nakładów na działalność badawczo-rozwojową do średniej wartości tego wskaźnika dla państw OECD, tj. do poziomu ok. 2,5\% PKB w 2030 r. oraz wzmocnienie autonomii finansowej uczelni poprzez zwiększenie elastyczności w wydatkowaniu środków przekazywanych im przez państwo, które w przekonaniu reformatorów mają spowodować dołączenie polskich uczelni do grona najlepszych. Interesującym 
pomysłem jest również wprowadzenie konkursów w ramach programu „Inicjatywa doskonałości dla uczelni badawczych" oraz w ramach programu „Regionalna inicjatywa doskonałości", które znacząco zwiększać będą środki finansowe zwycięskich uczelni. Szkoda jednak, że przy okazji nie zdecydowano się na wprowadzenie odważniejszych zmian i nie wprowadzono mechanizmów powodujących, że pieniądze dla uczelni będą szły za studentem. Pomimo istniejących ograniczeń konstytucyjnych można się było pokusić o wprowadzenie systemów premiujących uczelnie wyróżniające się pod względem dydaktycznym, a wprowadzenie dzięki temu konkurencji między uczelniami mogłoby pozwolić na lepsze dostosowywania oferty dydaktycznej do potrzeb rynku edukacyjnego. Niestety, bez tego typu rozwiązań jakość kształcenia na polskich uczelniach wyższych raczej nie poprawi się znacząco.

Mając na uwadze wieloletnie niedofinansowanie polskiej nauki, cieszyć się należy, że nakłady na naukę wreszcie zostaną zwiększone, ale tempo i zasady ich przyznawania sprawiają, że w dającej się przewidzieć przyszłości Polska raczej nie dołączy do państw najbardziej innowacyjnych. Niepokój każdego obserwatora dyskusji na temat finansowania i funkcjonowania polskich uczelni i polskiej nauki budzi wiara reformatorów, że nowy system, wolny od obecnych ograniczeń, będzie lepszy od dotychczasowego. Pozostawiając na boku pytanie, co sprawia, że nowy system ma być lepszy, warto przypomnieć starą mądrość, że lepsze jest wrogiem dobrego. Nie uważamy absolutnie, że obecny system nie wymaga zmian, ale trzeba pamiętać, że były jakieś powody, dla których stworzono tak rozbudowany system zasad regulujących zarządzanie uczelnią i jej strukturami. Co więcej, decentralizacja i upodmiotowienie podstawowych jednostek organizacyjnych uczelni w zakresie prowadzenia studiów wyższych, studiów doktoranckich, w zakresie nadawania stopni naukowych oraz oceny działalności naukowej i dydaktycznej nie jest wadą. Przeciwnie, chociaż ograniczać one mogą instrumentalnie skuteczne zarządzanie uczelnią przez rektora, to są one wyrazem i gwarantem podmiotowości wewnętrznej społeczności akademickiej. Być może należy przemyśleć i zmienić zasady ich funkcjonowania, ale czy na pewno należy je likwidować? Niby dlaczego przeniesienie uprawnień do prowadzenia kierunków studiów i nadawania stopni naukowych z poziomu wydziałów na poziom uczelni ma służyć podniesieniu jakości nauczania. Dlaczego szkoły doktorskie mają podnieść poziom doktoratów? Czy aby nowy model kształcenia doktorantów, zakładający m.in. likwidację niestacjonarnych studiów doktoranckich oraz nowe zasady przyznawania uprawnień do nadawania stopnia doktora nie są po prostu wyrazem wiary w mit, że da się wyhodować „idealnego uczonego"?

Kolejne zdziwienie, jakie budzi reforma, to uzasadnianie potrzeby zmian $\mathrm{w}$ organizacji i ustroju uczelni wyższych brakiem udziału interesariuszy zewnętrz- 
nych w ich życiu. Zdziwienie to wynika stąd, że przyczyną takiego stanu rzeczy wcale nie musi być wadliwy ustrój uczelni. W praktyce jest to rezultat niskiego stopnia rozwoju oraz ograniczonego potencjału ekonomicznego i mało innowacyjnego profilu polskich przedsiębiorstw, a tym samym niekompatybilności celów uniwersytetu i potrzeb rynku pracy. W wielu przypadkach czynnikiem decydującym o braku współpracy jest niestety także czynnik ludzki. Zamiast więc otwierać nowe uniwersytety lub zmieniać organizację już istniejących, należałoby może zapewnić, aby osoby zarządzające uniwersytetami i uczelniami wyższymi dawały rękojmię sprawnego zarządzania uczelnią i rozliczane były z efektów współpracy z interesariuszami zewnętrznymi. Ponadto zamiast otwierać kolejne uniwersytety, może należy tworzyć więcej uczelni zawodowych lub technicznych skupionych przede wszystkim na przygotowywaniu absolwentów do wykonywania wysoko wyspecjalizowanych zawodów?

Mając na uwadze środki finansowe, jakimi obecnie dysponują polscy uczeni i polskie uczelnie wyższe, można zaryzykować tezę, że nawet jeśli wprowadzimy ustawowo podział na uczelnie badawcze, uczelnie zawodowe czy jakiekolwiek inne, lepiej nie będzie, jeśli w sposób zasadniczy nie wzrosną nakłady finansowe na naukę i szkolnictwo wyższe. Bez rzeczywistej zmiany systemu finansowania nauki i znaczącego zwiększenia nakładów finansowych na szkolnictwo wyższe, bez realnej zmiany zasad wynagradzania pracowników uczelni i instytutów badawczych oraz bez stworzenia skutecznych mechanizmów komercjalizacji wyników pracy naukowej, bez względu na kształt regulacji, wiele się nie zmieni. Chociaż reforma przewiduje w tym zakresie pozytywne zmiany, o czym wspominaliśmy powyżej, to jednak w dość zaskakujący sposób zamiast wprowadzać rozwiązania sprzyjające konkurencji i koncentracji środków przeniknięta jest duchem egalitaryzmu i równego obdzielania wszystkich. Szczególnym przejawem takiego podejścia jest związanie minimalnych wynagrodzeń pracowników uczelni z wynagrodzeniem profesora oraz zagwarantowanie wszystkim doktorantom stypendiów naukowych.

Niestety związanie minimalnych pensji pracowników naukowych z wynagrodzeniem profesora, bez jasnych kryteriów ustalania wysokości tego ostatniego, ani nie gwarantuje długoterminowo prestiżu materialnego naukowców, ani nie gwarantuje zwiększenia aktywności i mobilności kadry akademickiej. Szkoda, że wynagrodzeń nie powiązano ze średnim wynagrodzeniem w sektorze przedsiębiorstw państwowych albo nie przyjęto rozwiązań zachodnioeuropejskich, wiążących wynagrodzenie pracowników nauki i szkolnictwa wyższego z wynagrodzeniami w sektorze administracji publicznej. Rozwiązanie obecne wbrew deklaracjom nie tylko nie gwarantuje naukowcom korzystania ze wzrostu gospodarczego, ale dodatkowo, mając na uwadze dynamikę wzrostu płac na rynku, utrwalać będzie upadek i pauperyzację tego środowiska. Niestety reformatorzy nie zaryzykowali dalej 
idących zmian, które mogłyby rzeczywiście wstrząsnąć polską nauką. Wciąż za niepowodzenia wolimy oskarżać mityczny system, niż przyznać, że kieruje nami strach przed mechanizmami wprowadzającymi realną konkurencję, która spowodować może znaczne zmiany kadrowe na wszystkich szczeblach i upadek słabszych uczelni. Dlatego jako niewystarczające ocenić należy przyjęte w ustawie regulacje dotyczące postępowań konkursowych w zatrudnianiu nauczycieli akademickich. Nie powstrzymają one ewentualnych patologii w tych postępowaniach, tym bardziej, że nie zdecydowano się wprowadzić zakazu zatrudniania uczelniom swoich absolwentów, w tym świeżo upieczonych doktorów, zanim nie wygrają oni konkursu na stanowisko akademickie na innej uczelni wyższej i nie przepracują w niej kilku lat. Rozwiązanie takie mogłoby przeciwdziałać nepotyzmowi i spowodować większą mobilność kadry, ale wiązałoby się z koniecznością stworzenia znacznie większych gwarancji socjalnych dla kadry akademickiej.

Jeszcze więcej zastrzeżeń budzi drugie rozwiązanie, gwarantujące wszystkim doktorantom stypendia naukowe. Likwiduje ono praktyczną potrzebę walki o granty doktorskie. To, że obecny system grantów doktorskich, w znacznej mierze oparty o działalność NCN, daleki był od doskonałości, nie zmienia faktu, że oparty był o mechanizmy naukowej konkurencji. Trudno powiedzieć na czym opiera się wiara, że obdzielenie doktorantów gwarantowanymi stypendiami podniesie jakość ich pracy, ale na pewno nie wynika ona z doświadczenia z pracy w komisjach przyznających granty doktorskie studentom, ani z pracy z doktorantami. Z naiwnością graniczy przekonanie, że zapewnienie wszystkim doktorantom stypendiów naukowych spowoduje, że będą zajmować się tylko pracą naukową i że podniesie to jej jakość. W obecnej sytuacji, kiedy prawie na wszystko w szkolnictwie wyższym brakuje pieniędzy, należałoby poważnie się zastanowić, czy nie lepiej by było zamiast rozpraszać środki, jakie mamy, i obdzielać wszystkich po trochu, skumulować je i przeznaczać znacznie większe kwoty na projekty i wynagrodzenie badaczy, którzy uzyskują najwyższe oceny od międzynarodowych gremiów eksperckich. Chociaż stanowisko takie może budzić kontrowersje, czasem lepiej jest się przyznać, że nie stać nas po prostu na wspieranie wszystkich w takim samym stopniu bez względu na wartość programu badawczego. Wprowadzone ustawą rozwiązanie wydaje się tym bardziej niezrozumiałe, że prowadzi ono nieuchronnie do skutków odwrotnych niż deklarowane przez jej twórców. Doktoranci i ich projekty badawcze nie będą musiały być porównywane w ogólnopolskich konkursach, w których zaangażowani są międzynarodowi recenzenci, a jedynie porównywane i oceniane będą w lokalnych konkursach organizowanych w ramach danej uczelni. Zamiast więc umiędzynarodowienia polskiej nauki już na tym etapie proponuje się system, który wspiera lokalne standardy i lokalne gremia naukowe, które je promują. Z aprobatą należy odnieść się jednak do wprowa- 
dzenia powszechnego systemu urlopów macierzyńskich i tacierzyńskich dla doktorantów.

Powyższe rozważania koncentrowały się na wątpliwościach, jakie budzi nowe prawo o szkolnictwie wyższym i nauce. W oczywisty sposób, ze względu na zakres niniejszego opracowania, pominęliśmy wiele kwestii szczegółowych. Poza przeprowadzonymi rozważaniami pozostały też rozwiązania, które w naszej opinii zasługują jednoznacznie na poparcie, takie jak chociażby nowa ścieżka kariery dydaktycznej dla wybitnych dydaktyków, w prowadzenie rozwiązań promujących jakość, a nie ilość publikacji oraz wsparcie finansowe dla polskich czasopism naukowych. Inne, takie jak zniesienie obowiązku habilitacji, w prowadzenie ułatwień w procesie jej uzyskiwania w określonych sytuacjach, czy wprowadzenie zasady, że ocena badań naukowych ma się odbywać $\mathrm{w}$ ramach całej uczelni, a nie na poziomie wydziałów, zawsze będą budzić kontrowersje i polemikę. Dopiero czas pokaże, czy zmiany te spełnią oczekiwania reformatorów, czy znów grozi nam kolejna „niedokończona reforma”? Czy można bez jednoznacznego określenia celu i przezwyciężenia wszechobecnych "mitów” dokonać jakiegokolwiek postępu w procesie reformowania uniwersytetu? Nie znajdujemy żadnych poważniejszych argumentów, które mogłyby uzasadniać w przypadku pierwszego pytania negatywną, a w przypadku drugiego pozytywną odpowiedź. Cóż więc pozostaje? Pewnie, jak to zwykle w Polsce - poczekać! 